DOI https://doi.org/10.30525/978-9934-26-075-9-23

\title{
УПРАВЛІННЯ РИЗИКАМИ ПРИ ПРОВЕДЕННІ ГЕМАТОЛОГІЧНИХ ДОСЛІДЖЕНЬ
}

\author{
Салімонович А. А. \\ студентка \\ Національний фармацевтичний університет \\ Єрьоменко Р. Ф. \\ доктор біологічних наук, професор, \\ завідувач кафедри клінічної лабораторної діагностики \\ Національний фармацевтичний університет \\ Яценко О. Ю. \\ кандидат фармачевтичних наук, дочент, \\ дочент кафедри нормальної та патологічної фізіології \\ Національний фармацевтичний університет \\ м. Харків, Украӥна
}

На сьогодні медична галузь стрімко розвивається у всьому світі. Винаходять нові ліки, технології, у тому числі методи діагностики. Але існують золоті стандарти, які продовжують використовувати у багатьох ситуаціях. Одним з таких методів дослідження є клінічний аналіз крові. Одним 3 показників, який визначається при клінічному дослідженні, $\epsilon$ рівень гемоглобіну.

Дослідження рівня гемоглобіну $\epsilon$ актуальним в багатьох аспектах медичної діяльності. Це дослідження проводиться з профілактичною метою під час проведення щорічних медичних оглядів працівників [7], дітей [9], обстеженні вагітних [8]. Визначення гемоглобіну призначається хворим 3 загальною патологією: хірургічні, терапевтичні захворювання, патології внутрішніх органів тощо. Виключне значення має дослідження рівню гемоглобіну у гематологічних хворих, що дає змогу встановити діагноз, відстежувати динаміку перебігу хвороби та коригувати призначене лікування [1]. Таким чином, визначення рівню гемоглобіну $\epsilon$ безперечно важливим у лікуванні та профілактиці багатьох станів.

Дуже важливо забезпечити високу якість проведення аналізу крові, адже тільки точні, достовірні та своєчасні результати дають змогу адекватно оцінити стан хворого та призначити відповідне лікування. Досягти цього можливо за умови провадження системи управління 
якістю відповідно до міжнародних стандартів (МС). Однією зі складових такої системи є ризик - менеджмент, який передбачає ідентифікацію, оцінку ризиків та визначення відповідних попереджувальних та коригувальних дій [4].

Ризик - це невизначеність щодо досягнення цілей [5]. Тобто будьякий фактор, який може вплинути на точність, достовірність та своєчасність дослідження рівню гемоглобіну, має бути ідентифікований та оцінений. Відомо, що будь-яке лабораторне дослідження має три етапи: преаналітичний, аналітичний та постаналітичний [3]. На кожному з них необхідно визначити фактори, які можуть вплинути на результат дослідження.

Визначення рівню гемоглобіну може бути проведено рутинним методом або $з$ використанням гематологічного аналізатору [2]. Нами буди досліджені та визначені чинники впливу на кожному з етапів проведення дослідження.

На преаналітичний етап припадає до 68\% всіх лабораторних помилок [6]. Будь-яке дослідження, зокрема визначення рівню гемоглобіну, починається з його призначення лікарем. Лікар повинен чітко розуміти, що він має на меті та який аналіз повинен бути призначений, а також якими $є$ строки проведення аналізу (плановий чи терміновий). Для цього він повинен бути компетентним та користуватися затвердженими у рамках доказової медицини протоколами. Необхідно приділяти увагу правильній ідентифікації пацієнта. Значущість цього ризику визначається, в певній мірі, видом медичного закладу та станом пацієнту: чи може він самостійно надати дані про себе, чи це пацієнт без свідомості, та його ідентифікація може викликати труднощі. В будь-якому випадку велике значення має уважність персоналу та точність маркування пробірок з кров’ю.

Для виконання клінічного аналізу крові та зокрема визначення рівню гемоглобіну досліджується капілярна чи венозна кров, яка набирається у спеціальну пробірку, що містить антикоагулянт ЕДТА. Для забору капілярної крові використовують мікровети, венозної - вакутейнери. Мікровети містять тільки один вид антикоагулянту, тому помилка 3 вибором пробірки в цьому випадку виключена. Для взяття венозної крові випускається декілька видів вакутейнірів, які містять різні реагенти та призначені для різних досліджень, тому існує ризик неправильного вибору пробірки, що призводить до неможливості виконання дослідження. Важливо дотримуватися методики забору крові, для чого ці методики повинні бути задокументовані, а персонал лабораторії повинен бути ознайомлений з ними. Після взяття крові проба повинна бути ретельно перемішана задля уникнення виникнення згустків, що може призвести до отримання заниженого значення рівню гемоглобіну 92 
або неможливості проведення дослідження. Отримана первинна проба повинна бути доставлена до лабораторії у визначені для цього терміни. Ризик невиконання цієї вимоги підвищується, якщо забір крові відбувається поза лабораторією.

Доставлені до лабораторії проби повинні бути належним чином зареєстровані. На цьому етапі важливо проводити відбраковку непридатних для дослідження проб згідно заздалегідь встановлених критеріїв. Це правильне маркування, наявність супровідної документації, що забезпечує належну простежуваність проби, достатня кількість біологічного матеріалу та відсутність згустків, дотримання строків доставки. Інформація про непридатність проби повинна бути одразу доведена до відома персоналу, який задіяний у преаналітичному етапі з метою взяття нової первинної проби якомога скоріше. На наш погляд, це один 3 критичних моментів проведення дослідження, особливо коли процеси преаналітичного етапу проводяться поза лабораторією та відповідальність за них покладена на різних людей та різні підрозділи медичної установи.

Придатні до дослідження проби потрапляють до аналітичного етапу. Ризики, які можуть виникати на цьому етапі, пов'язані з безпосередньо визначенням рівня гемоглобіну в досліджуваний пробі, проведення внутрилабораторного контролю якості та ведення документації.

При визначенні рівня гемоглобіну за допомогою гематологічного аналізатору необхідно дотримуватись інструкції та проводити регулярний контроль якості. Особливу увагу необхідно приділяти своєчасній повірці та технічному обслуговуванню обладнання.

При визначенні рівню гемоглобіну рутинним методом велику роль грає людський фактор, що обумовлює необхідність приділення особливої уваги кваліфікації персоналу медичної лабораторії. На отриманий результат можуть вплинути похибки піпетування при постановці досліджуваної та калібрувальної проб, точність приготування трансформуючого розчину та відмірювання реактиву, правильність настройки спектрофотометра, інтерпретації результату.

Контроль якості проводиться регулярно одночасно 3 аналізуванням досліджуваних проб. Необхідно контролювати умови зберігання та строки придатності контрольного матеріалу. При використанні рутинного методу, окрім цього, існують ті ж самі ризики, що були визначені для аналізування досліджуваної проби.

Усі отримані результати повинні бути належним чином зареєстровані. На сьогодні у всіх галузях багато уваги приділяється комп'ютеризації, у тому числі в сфері надання медичних послуг. При цьому лабораторії не відмовляються і від ведення журналів обліку. На точність реєстрації результатів дослідження впливають уважність медич- 
ного персоналу, належне технічне оснащення, вміння користуватися комп'ютером.

Якість дослідження щодо визначення гемоглобіну передбачає не тільки точність та достовірність результату, а й своєчасність його отримання лікарем. Деякі стани пацієнтів потребують оперативного визначення рівня гемоглобіну з метою швидкого його коригування. В такому випадку ризик несвоєчасного отримання результатів дослідження може мати фатальні наслідки. В лабораторії має бути розроблений ефективний механізм передачі результатів аналізу лікарю в електронному вигляді чи на паперовому носії.

Медичні лабораторії використовують різні методики для дослідження рівня гемоглобіну, володіють різним обладнанням, технічними можливостями, мають персонал різної кваліфікації. Відповідно до цього кожна лабораторія має ідентифікувати та оцінити ті ризики, які мають місце саме в цій установі, розробити необхідні коригувальні та попереджувальні дії. Таким чином, впровадження системи ризик-менеджменту дозволить підвищити якість проведення дослідження та знизити кількість медичних помилок.

\section{Література:}

1. Базарнова М.А., Воробьёв А.И., Баркаган 3.С. и др. Руководство по клинической лабораторной диагностике Ч.1-2: учебное пособие / под ред. М.А. Базарновой, А.И. Воробьёва. 2-е изд., перераб. и доп. Киев, 1991. 615 с.

2. Волкова С.А., Боровков Н.Н. Основы клинической гематологии: учебное пособие. Нижний Новгород: НижГМА, 2013. 400 с.

3. ДСТУ EN ISO 15189:2015. Лабораторії медичні. Вимоги до якості та компетентності. Київ, 2015. 111 с.

4. ДСТУ IEC/ISO 31010:2013. Керування ризиком. Методи загального оцінювання ризику. Київ, 2015. 73 с.

5. ДСТУ ISO Guide 73:2013. Керування ризиком. Словник термінів. Київ, 2014. 13 с.

6. Максимюк Г.В. Імплементація стандартизованих умов преаналітичного етапу в роботу клініко-діагностичних лабораторій. Вісник проблем біологї і медищини. 2017. № 1. С. 46-52.

7. Про затвердження Порядку проведення медичних оглядів працівників певних категорій: Наказ МОЗ України від 21.05.2007 № 246 / MO3 України. URL https://zakon.rada.gov.ua/laws/show/z0846-07\#Text (дата звернення 28.03.2021).

8. Про організацію амбулаторної акушерсько-гінекологічної допомоги в Україні Наказ МО3 України від 15.07.2011 №417 / МО3 України. 
URL https://zakon.rada.gov.ua/rada/show/v0417282-11\#Text (дата звернення 28.03.2021).

9. Про удосконалення медичного обслуговування учнів загальноосвітніх навчальних закладів: Наказ МО3 України від 16.08.2010 № 682 / MO3 України. URL https://zakon.rada.gov.ua/laws/show/z079410\#Text (дата звернення 28.03.2021).

DOI https://doi.org/10.30525/978-9934-26-075-9-24

\section{ЗНАЧЕННЯ КОМПЛЕКСНОГО НЕЙРОВІЗУАЛЬНОГО ОБСТЕЖЕННЯ ХВОРИХ НА ЦЕРЕБРОВАСКУЛЯРНІ ЗАХВОРЮВАННЯ}

\section{Степаненко I. B.}

доктор медичних наук, старший науковий співробітник, завідувачка відділення нейрореабілітації ДУ «Інститут нейрохірургї імені академіка А. П. Ромоданова Національної академії медичних наук України»

Попова І. Ю.

кандидат медичних наук, лікар відділення нейрореабілітаиіі

ДУ «Інститут нейрохірургії імені академіка А. П. Ромоданова Начіональної академії медичних наук Украӥни»

Лукашевич П. В.

кандидат медичних наук, лікар відділення нейрореабілітації

ДУ «Інститут нейрохірурсї імені академіка А. П. Ромоданова Національної академії медичних наук України»

\section{Лихачова Т. А.}

лікар відділення нейрореабілітаиії

ДУ «Інститут нейрохірургї імені академіка А. П. Ромоданова Національної академії медичних наук Украӥни» м. Київ, Україна

Уточнення характеру змін головного мозку при цереброваскулярних захворюваннях різної тяжкості має велике значення для об'єктивної 